\title{
The meanings of monuments and memorials: toward a semiotic approach
}

\section{Federico Bellentani and Mario Panico}

This paper aims at delineating the basic principles for a semiotic approach to monuments and memorials. Monuments are built forms erected to confer dominant meanings on space. They present an aesthetic value as well as a political function. Often, political elites erect monuments to promote selective historical narratives that focus on convenient events and individuals while obliterating what is discomforting. While representing selective historical narratives, monuments can inculcate specific conceptions of the present and encourage future possibilities. As such, monuments become essential for the articulation of the national politics of memory and identity through which political elites set political agendas and legitimate political power. However, once erected, monuments become social properties and users can reinterpret them in ways that are different or contrary to the intentions of the designers.

Previous research has explored monuments as either aesthetic objects presenting historical and artistic values or as political tools in the hand of those in power. Hence, this research has wittingly or unwittingly created a gap between the material-symbolic and the political dimensions of monuments. Moreover, it has variously given more emphasis either to the intentions of the designers or to the interpretations of the users.

The semiotic approach to monuments can address these issues providing a holistic approach that overcomes the rigid distinctions predominant in previous research on monuments. Although useful analytical categories, the distinction between material-symbolic and political dimensions cannot be extended to the ontological state of monuments. Semiotics can be useful in investigating the meanings of monuments as actively created by the interplay of the material, the symbolic and the political dimensions. It provides a methodological basis to consider designers and users as equally contributing to the meaning-making of monuments.

KEYWORDS monuments and memorials, semiotics of culture, national identity, memory, meanings.

\section{Introduction}

Dictionaries of contemporary English define monuments and memorials emphasizing their commemorative functions: whatever their appearance or size, monuments are built forms explicitly erected to remind people of important events and individuals ${ }^{1}$, but important for whom? Often contemporary states privilege dominant groups. As part of the state, urban planning can be used to serve the needs of political elites (Yiftachel 1998). And so is for monument design: political elites have more power and resources to establish monuments and memorials (Dwyer 2002: 32; Till 2003: 
297). Political elites use monuments to represent their dominant worldviews in space. Consequently, monuments represent selective historical narratives focusing only on events and identities that are comfortable for political elites.

This is particularly evident in the post-socialist city (Tamm 2013). During transition, political elites in post-socialist countries established new monuments to celebrate the kinds of ideals they wanted citizens to strive toward. Often, this process was simultaneously supported by the reconstruction, relocation and removal of monuments erected during Communism (Kattago 2015: 180). These interventions on Communist built environment are still going on in some post-socialist countries: for example, in April 2015 the Ukrainian government approved laws to enable the removal of Communist monuments.

However, these interventions on Communist monumental remains were far from being widely accepted and often resulted in heated political discussion, social tension and conflict ${ }^{2}$. The controversies around the meanings of monuments in post-socialist cities first show that monuments are not neutral urban decorations, but rather important sources of cultural identity and memory. Moreover, these controversies demonstrate that political elites cannot fully control how individuals and social communities interpret monuments. Once erected, monuments "can be used, reworked and reinterpret in ways that are different from, or indeed contradictory to, the intentions of those who had them installed" (Hay et al. 2004: 204).

The study of monuments has so far remained rather marginal within the humanities and social sciences. One reason for this may have been that a multitude of disciplines have studied monuments from different points of view. As a consequence, the term monuments has become vaguely defined, ranging from purely aesthetic built forms to powerful tools to reproduce authority and control. Urban and art history have explored monuments as aesthetic objects, focusing on their immanent historical and artistic values. Human and cultural geography has analyzed monuments as political tools to legitimize the power of political elites. While urban and art history has largely underestimated the political dimension of monuments, human and cultural geographers have rarely explored how the material and symbolic aspects relate to the political dimension of monuments.

In this paper, we propose a holistic approach to describe how these various aspects overlap and reinforce each other in the meaning-making of monuments. The semiotic approach to monuments can provide adequate tools to investigate the material, the symbolic and the political dimensions of monuments as interdependent. In doing so, semiotics can revise the rigid distinctions that have characterized previous research on monuments, such as material/symbolic, visual/political, art/power, designer/user. Semiotic analysis accounts for the "dialogicity" of meanings circulating around monuments and specifically for the interplay between designers' and users' interpretations (Lindström et al. 2014: 126). Finally, semiotics can be useful to explore how different individuals and social communities differently interpret monuments.

In section 2, we review the main theoretical and analytical approaches to the meaning-making of monuments. In section 3, following proposals in semiotics of text, we propose a model that considers designers and users as equally contributing to the meaning-making of monuments. In section 4, we distinguish meanings in four autonomous but related functions: the cognitive, the axiological, the emotional and the pragmatic. In section 5, we describe two autonomous but related dimensions of monuments: the visual, divided in material and symbolic, and the political. The distinction between visual and political dimensions is a useful analytical tool, but it cannot be projected onto the ontological state of monuments: in practice, visual and political dimensions always function together and influence each other through continuous mediations. In section 6, we explain that cultural context and specifically the surrounding built environment largely affect the meaning-making of monuments. 


\section{How have monuments been studied?}

The study of monuments has so far remained rather marginal within the humanities and social sciences. However, there have been a significant number of studies focusing on different aspects of monuments. Urban and art historians have considered monuments as physical and aesthetic objects presenting historical and artistic value. In this context, researchers have investigated the stylistic context in which monuments are erected with great emphasis on the visual dimension of monuments, describing in detail materials of construction, size and colors. Iconography has been broadly used to identify the conventional symbols represented in monuments. Other approaches have called for a more interpretative understanding of monuments using "iconology" to explore the "intrinsic meanings" that reveal "the basic attitude of a nation, a period, a class, a religious or philosophical persuasion" (Panofsky 1955: 38).

Sociological and anthropological literature has mainly focused on the commemorative functions of monuments drawing attention to the practices of commemoration of the users. In this context, monuments have been considered as built forms erected to commemorate the events and the individuals that are significant for a group or for a community. Alois Riegl has explained that commemoration has been the traditional function of monuments since their origins:

A monument in its oldest and most original sense is a human creation, erected for the specific purpose of keeping single human deeds or events [...] alive in the mind of future generations. (Riegl 1903: 117)

Riegl has also outlined the criteria that governments should consider when approaching the preservation of monuments. In his opinion, monuments should be preserved when they present a combination of artistic and historical values. Similarly, Roger W. Caves has shown that the preservation of monuments depends on both artistic values and commemorative functions. He has stated that a monument is:

A construction or an edifice filled with cultural, historical and artistic values. The conservation and maintenance of monuments is justified by those values. Historically, the idea of the monument is closely tied to commemoration (of a victory, a ruling, a new law). In the urban space, monuments have become parts of the city landscape, spatial points of reference or elements founding the identity of a place. Monuments can be enriched by educational and political functions [...] as well as artistic ones and those centered on commemoration. (Caves 2005: 318)

Geographers have used a different approach that considers the commemorative functions of monuments as essentially political. Since David Harvey (1979) analyzed the political controversy over the building of the Sacré-Coeur Basilica in Paris, broad and diverse research within human and cultural geography has considered monuments as tools in the hand of those in power to promote specific historical narratives and dominant worldviews (Hershkovitz 1993; Johnson 1995; Osborne 1998; Atkinson \& Cosgrove 1998; Whelan 2002; Hay et al. 2004; Benton-Short 2006). This research has broadly investigated how monuments can create selective historical narratives. In doing so, some geographers have considered monuments as "sites of memory" (Nora 1996: XVII), i.e. material, symbolic and functional sites able to "frame and shape the content of what is remembered" (Kattago 2015: 7). Since memory is the basis for any identity building, geographers have highlighted the role of monuments in defining collective and national identity. In this context, they have investigated how political elites use monument to shape and reinforce sentiments of national distinctiveness and unity (Hobsbawm and Ranger 1983; Anderson 1983). 
The aim of this geographical research has been to unveil the dominant discourses embodied in monuments: what history, ethnicity, gender and nationality have been represented in monuments and what have been obscured or obliterated? Is this oblivion deliberately planned so as to create a dominant "landscape of remembrance" (Johnson 1995: 56)?

The geographical study of monuments has broadly grounded itself on the rigid opposition between designers and users. Some geographers have considered the interpretations of users as spontaneous reactions to the more prominent meanings of political elites. Accordingly, they have assumed that "dominant cultures" had more power to convey their worldviews in space (Cosgrove 1989: 127).

Other geographers have considered monuments as potentially supporting every possible interpretation beyond designers' intentions. In this case, "alternative cultures" (Cosgrove 1989: 131) interpret monuments in ways that are "different or even contrary to the uses to which their builders or "owners' intended they be put" (Hershkovitz 1993: 397). Specifically, this approach has focused on contentious political circumstances in which oppositional and resistant movements "appropriate" monuments and "transform" them "into symbolic forms which take on new meanings and significance" (Cosgrove and Jackson 1987: 98-99).

Although the distinction between designer and user can be a useful analytical tool, we argue that designers and users equally contribute to the creation and development of the meaning of monuments. Following proposals in semiotics of text, the next section proposes to overcome the rigid division between designers and users.

\section{The interpretation of monuments between designers and users}

While reviewing contemporary theories of interpretation in the literary domain, Umberto Eco (1986) explains that research in textual interpretation has been polarized between those assuming that texts can be interpreted only according to the intentions of the authors and those considering text as supporting multiple interpretations. Later, Eco (1990a, 1992) suggests that interpretation lies in an intermediate position between these two poles, i.e. between the authors' and readers' intentions ${ }^{3}$.

This view overcomes the idea that "appropriate" interpretations occur only when texts are interpreted according to the intentions of the authors. Nevertheless, it takes into account that several strategies are available to the authors to control readers' interpretations. Eco groups together these strategies under the terms "Model Reader" (Eco 1979: 7-11). According to this model, authors simultaneously presuppose and construct their readership making assumptions about its social background, education, cultural traits, tastes and needs. As a consequence, texts always refer to specific readerships, anticipating certain interpretations while resisting others (Eco 1979: 7-11; Lotman 1990: 63).

Although authors seek to control users' interpretations, texts do not function as mere "communicative apparatuses" directly imprinting meanings to readers (Eco 1986: 25). Instead, texts are aesthetic productions always leaving something unexplained:

Every text, after all [...], is a lazy machine asking the reader to do some of its work. What a problem it would be if a text were to say everything the receiver is to understand - it would never end. (Eco 1994: 3)

As aesthetic productions, texts become the "loci" where both authors and readers continuously negotiate their interpretations: on the one hand, authors seek to control readers' interpretations; on the other hand, readers interpret texts according to their needs. Yet, certain constraints limit the range of interpretations that texts may elicit: 
To say that interpretation (as the basic feature of semiosis) is potentially unlimited does not mean that interpretation has no object and that it "riverruns" merely for its own sake. To say that a text has potentially no end does not mean that every act of interpretation can have a happy end. (Eco 1990b: 143)

Hence, the issue on the limits of interpretations can be overcome exploring the complex interactions between authors, readers and texts themselves. As Yanow states:

[...] meaning resides not in any one of these - not exclusively in the author's intent, in the text itself, or in the reader alone - but is, rather, created actively in interactions among all three, in the writing and in the reading. (Yanow 2000: 17)

Similarly, built environment as text anticipates a set of interpretations and uses while resisting others. Designers use several spatial strategies to create interpretative habits and pull users along a specific understanding of built environment. Paraphrasing Eco's Model Reader, Marrone (2009, 2010, 2013) calls "Model Users" those users that conform to these interpretative habits and use built environment according to the designers' intentions.

In an essay about architecture, Eco (1997) argues that, through specific design choices, designers can persuade users to interpret architecture the way they wish. Hence, architecture itself gives instructions on its "appropriate" use:

Architectural discourse is psychologically persuasive: with a gentle hand (even if one is not aware of this as a form of manipulation) one is prompted to follow the 'instructions' implicit in the architectural message; functions are not only signified but also promoted and induced. (Eco 1997: 196)

However, designers can never fully predetermine the interpretation of the built environment, as authors cannot control readers' interpretations. In fact, only some users conform to the Model User and interpretations diverging from the designer's intentions may arise. Consequently, a built environment can be used in ways the designers would never have thought of.

Eco (1972; see also Fabbri and Eco 1981: 7-12) terms "aberrant decoding" when the interpretations of a message differ from what the authors anticipated. According to Eco, divergent decoding of architecture is mostly unconscious. He considers the messages of functional architectures such as buildings as being rather coercive and indifferent:

Architectural discourse is experienced inattentively [...]. Buildings are always around and people percept them as a background. [...] Architectural messages can never be interpreted in an aberrant way, and without the addressee being aware of thereby perverting them. [...] Thus architecture fluctuates between being rather coercive, implying that you will live in such and such a way with it, and rather indifferent. (Eco 1997: 196)

This is not the case of monuments and memorials: users may deliberatively interpret monuments in ways that are different or contrary to designers' expectations. Furthermore, users can turn monuments into spaces for resistant political practices. As concrete manifestations of political power (Hershkovitz 1997: 397), monuments have often been desecrated through resistant performances: as an example, in April 2016 demonstrators smeared with colored dye many statues and monuments in Skopje in sign of protest against the Macedonian government.

The model describing the complex relations between authors-readers-texts and between designers-users-built environments can be applied to monuments. The meanings of monuments are hardly fixed and depend on the complex relations between designers, users and monuments them- 
selves. Political elites use design strategies to generate interpretations that conform to their political purposes. Nevertheless, users may interpret monuments following their own opinions, beliefs, feelings and emotions. As a consequence, different and even contrasting interpretations often challenge the officially sanctioned meanings of monuments (see section 5.2). Lefebvre describes this capacity of monuments to generate multiple interpretations though the metaphor of "horizon of meanings":

A monumental work, like a musical one, does not have a 'signified' (or 'signifieds'); rather, it has a horizon of meaning: a specific or indefinite multiplicity of meanings, a shifting hierarchy in which now one, now another meaning comes momentarily to the fore, by means of - and for the sake of - a particular action. (Lefebvre 1974: 222)

The semiotic approach to monuments considers the meaning of monuments as always resulting from the interplay between designers' and users' interpretations. Moreover, the semiotic approach aims at exploring the meanings monuments come to have beyond individual interpretations - paraphrasing Eco, the "intentions" of monuments themselves.

\section{The functions of the meanings of monuments}

This section explores the meanings of monuments as divided in four interrelated functions: 1) the cognitive function refers to the kind of human knowledge monuments embody as well as the knowledge users have about the representations of monuments; 2) the axiological function considers whether users value this knowledge positively or negatively; 3 ) the emotional function investigates which emotions and feelings monuments elicit; and 4) the pragmatic function concerns the practices of users within the space of monuments. All these functions are only analytical: in practice, they are interdependent and act simultaneously in defining the meanings of monuments.

\subsection{Cognitive function}

From the mid-1980, cultural geographers began to investigate landscape" as "communicative devices that encode and transmit information" (Duncan 1990: 4). Similarly, monuments have been considered as "high symbolic signifiers" that confer meanings on space (Whelan 2002: 508; Benton-Short 2006: 299).

The cognitive function of monuments regards the kind of human knowledge monuments embody as well as the knowledge users have about the representation of monuments. The knowledge embodied in monuments is inevitably biased. As every narrative selects some events while omitting others (Cobley 2001: 7), monuments necessarily focus on some histories while obliterating others. Since every "remembering, nevertheless, involves a forgetting" (Dovey 1999: 73), it is natural that monuments represent only specific events and individuals.

Yet political elites can deliberately plan to obliterate certain histories (Lotman and Uspenskij 1975: 46; Lorusso 2010: 92). They can articulate specific national politics of memory to educate citizens toward what to remember and what to forget of the past (Tamm 2013: 651). In doing so, political elites seek to promote dominant historical narratives to accommodate their political purposes and to encourage future possibilities (Massey 1995: 185; Dovey 1999: 12).

However, users may interpret the knowledge embodied in monuments according to their views and needs. Different interpretative communities have different ways of identifying and interpreting the representation of monuments (Yanow 2000). The cognitive function concerns also this local knowledge ${ }^{5}$ users have about the events and the individuals represented in monuments. 


\subsection{Axiological and emotional functions}

The knowledge users have about monuments affect how they value the events, ideals and individuals represented in monuments. The axiological function concerns whether users positively or negatively value what monuments represent and specifically how they assess the modes through which monuments stage their scenes. This evaluation is based on the axiological structure euphoria/ dysphoria (Greimas and Courtés 1982: 21). In less technical terms, euphoria relates to positive and attractive attitude toward monuments, while dysphoria is when monuments elicit negative or repulsive sentiments. As a consequence of these evaluations, monuments originate different emotional responses: which emotions and feelings do monuments elicit in users? Have users positive or negative attitudes toward what monuments represent?

In practice, each user has a different emotional response to monuments: in different users the same monument may elicit pleasant emotions or it may recall uncomfortable memories.

Greimas and Fontanille (1991) propose a semiotic model for the study of emotions and feelings at the narrative and discursive level. ${ }^{7}$ This model can be employed to study the fluctuation of emotional attitudes toward monuments and to explore how emotional attitudes affect the practices of users around monuments.

With reference to the axiological and the emotional functions, we distinguish between "hot" and "cold" monuments. ${ }^{6}$ In general terms, "hot" monuments can elicit in users uncomfortable or even traumatic emotions. They can stimulate fierce political debates that may result in forms of conflict and resistance at a social level. This situation occurs when there is a gap between the meanings promoted by political elites and how users differently interpret, contest and resist them. An example of a hot monument is the Red Army memorial of Tallinn: its presence in the heart of Tallinn recently became a touchy issue among Estonians. For this reason, in 2007, the Estonian government decided to relocate it outside the city. Some Tallinn citizens - especially those belonging to the large Russian minority living in Estonia - perceived this act as a provocation: for them, the memorial represented an important site of commemoration. As a result of this relocation, two nights of disorders broke out in Tallinn (for references about this case, see Note 2).

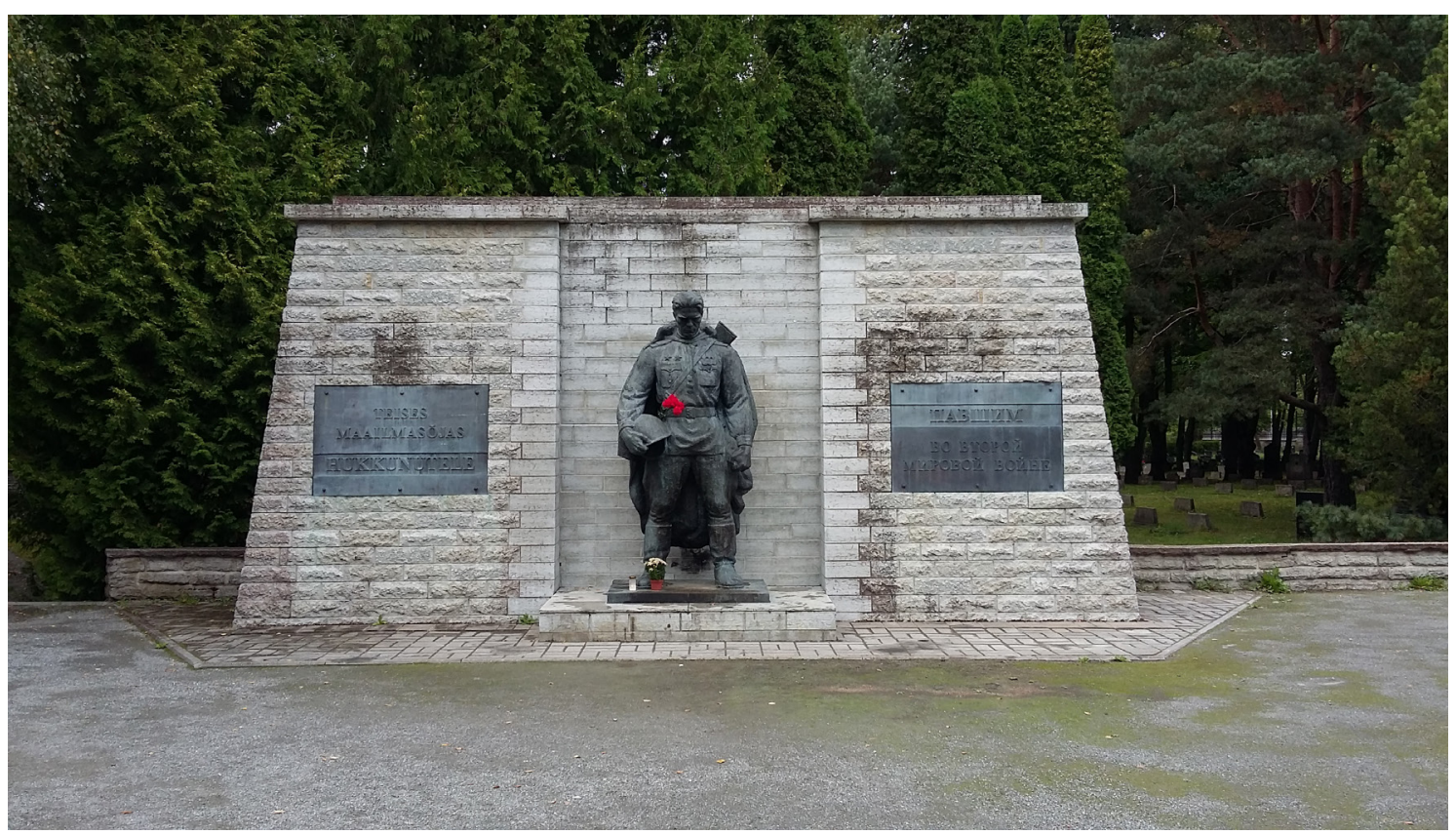

Figure 1. 
Conversely, "cold" monuments convey meanings that have become widely shared by a large part of users. For this reasons, the representations of cold monuments elicit no intense emotional reactions. Cold monuments are peacefully integrated into the everyday practices of users that perceive them as ordinary built forms. This is the case with monuments that have turned into neutral landmark or mere meeting points.

The category hot/cold should be understood as a continuum between two terms defining distinct attitudes toward monuments. Originally, monuments are not erected as hot or cold: accepted monuments can turn into sites of resistance as well as controversial monuments can increasingly become accepted and mindlessly experienced during the routine of daily life. The evaluations and emotional responses of users toward monuments vary as social and political conceptions change over time (Kosellek 2002: 187; Kattago 2015: 185). For example, in post-socialist cities, monuments erected during the Communist era have increasingly become sites of oppositional and resistant practices as a consequence of the shift in political, social and ethnic relations since the fall of Communism.

\subsection{Pragmatic function}

How users act around monuments largely depends on what they know about what the monument represents (cognitive function), whether they value positively or negatively this knowledge (axiological function) and on the emotions monuments elicit in them (emotional function).

Cold monuments are experienced as ordinary built forms within the public space. They have lost their ideological weight and turned into neutral landmarks or meeting points. Elsewhere, they have become sites for unexpected practices: for example the War of Independence Victory Column in Tallinn, capital of Estonia, a memorial erected by the Estonian government as a sacred site to commemorate soldiers who served in a struggle against Soviet Russia ${ }^{8}$ has turned into a place where youngsters do tricks with skateboards and BMX. Nevertheless, the Estonian government still uses the area around this memorial for formal practices of commemoration and other national rituals. Around the same monument, oppositional political groups have from time to time organized demonstrations against the Estonian government.

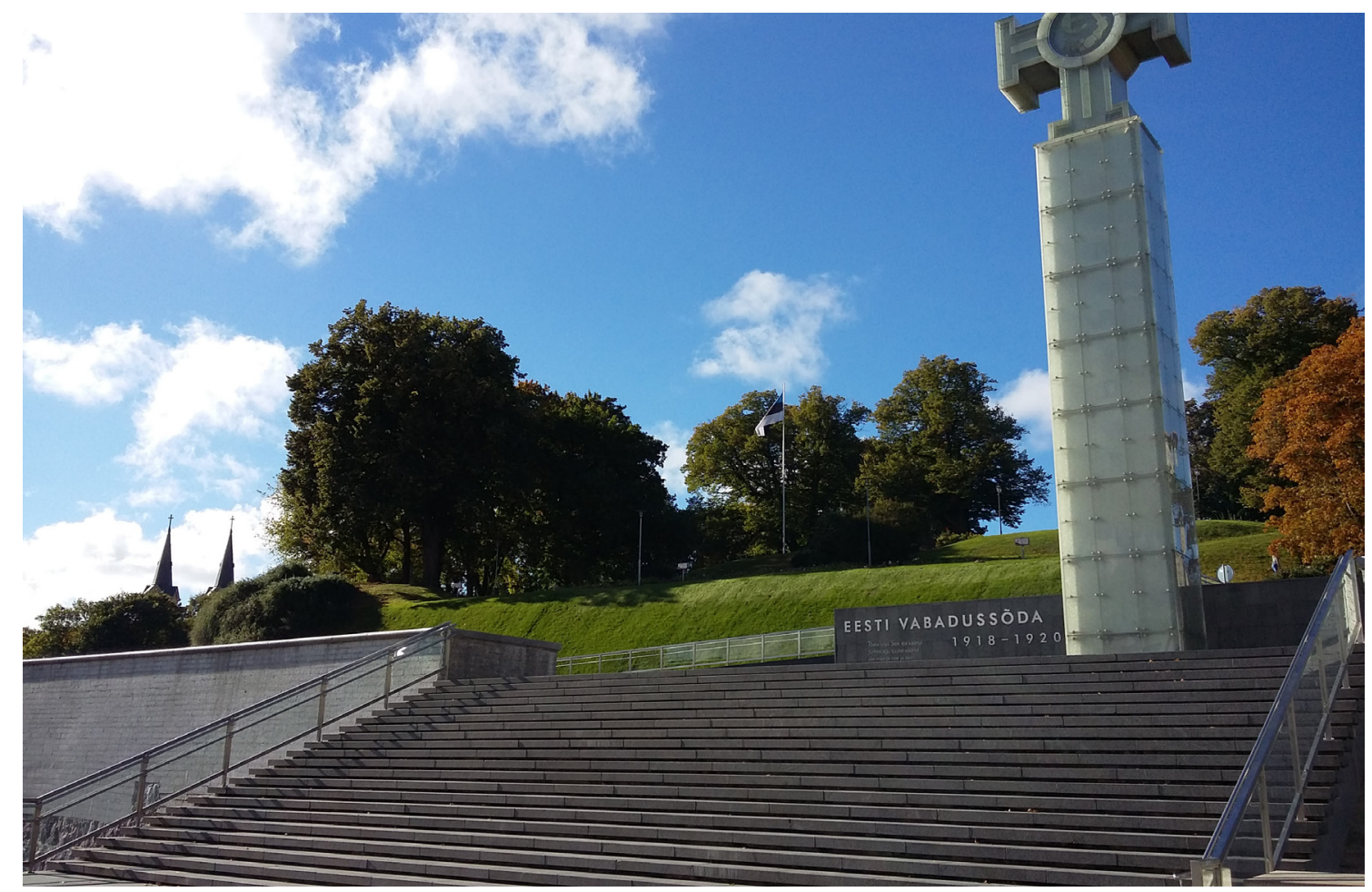

Figure 2. 
The semiotic approach considers the formal, the unexpected as well as the resistant practices as equally contributing to the meaning-making of monuments.

\section{The visual and the political dimensions of monuments}

This section investigates the visual and political dimensions of monuments. Previous research on monuments has proposed excellent methodological approaches to explore each of these dimensions in turn. Visual and political dimensions always function together and influence each other through continuous mediations.

\subsection{The visual dimension}

The visual dimension of monuments refers to monuments as material built forms beyond their political implications. It examines both the material features and the representations of monuments. Following the proposal of visual semiotics, we divide the visual aspect into two autonomous but related levels: the plastic and the figurative (Greimas 1984), respectively describable as the material and symbolic levels.

The material level considers shapes, colors and topological distribution of monuments as independent from their visual representations. Abousnnouga and Machin (2013: 41-57) proposed a list of categories to describe the material dimension of monuments. They explain that several "material semiotic choices" are available to designers in order to establish specific relations between monuments and users (Abousnnouga and Machin 2013: 16).

The list below shows the categories that we consider pertinent for the analysis of the material level of monuments. The list includes some of the semiotic choices by Abousnnouga and Machin (2013: 41-57) and some topological, eidetic and chromatic categories from plastic semiotic (Greimas 1984).

1. Dimensions: large/small, wide/narrow, tall/short;

2. Location: degree of elevation, distance/proximity, angle of interaction;

3. Materials of construction: solidity/hollowness, texture of the surface;

4. Topological organization: form, shape;

5. Eidetic organization: regularity/irregularity, curvature;

6. Chromatic organization: colors, brightness/opacity, lighting.

The symbolic level regards the visual representation of monuments. Since monuments stage specific scenes, the symbolic analysis of monuments focuses on the represented objects, characters and actions. It looks at the iconographies and the symbols that monuments embody.

Traditional research in visual semiotics (for example, Thurlemann 1982: 108) has associated the material and symbolic levels with the expression/content distinction. ${ }^{9}$ This approach has conceptualized expressions as ontological entities regarding the physical and visually perceptible aspects of texts. As such, expressions have become meaningless substances to which intangible meanings correlate. For this reason, traditional semiotic analyses have assumed that meanings can be "extracted" directly from the materiality of visual texts without active interpretation processes (Chandler 1995).

The same assumption has characterized more recent semiotic research on the meaning of monuments. For example, Abousnnouga and Machin (2013: 57) have analyzed war memorials in United Kingdom implying that material design choices are able to directly communicate specific meanings. The authors have explained that a "repertoire of semiotic resources" is available to designers who combine them "to communicate specific meanings in context". Moreover, they have argued that ma- 
terial and symbolic choices can "have very different meaning potential" (Abousnnouga and Machin 2013: 131): for example, stone as a construction material conveys "longevity and ancientness", but also "naturalness" and "softness" when carved in smooth and rounded shapes (Abousnnouga and Machin 2013: 134).

We argue that stone as a construction material cannot directly communicate specific meanings. Rather, stone signifies insofar as routinized patterns of interpretation are created, i.e. when semiotic resources has been repetitively used to convey certain meanings (Nanni and Bellentani, forthcoming). This is to say that, for example, a tall memorial cannot convey imposing meanings of power simply because of its stature or a glass sculpture cannot convey meanings of transparency only because of its material of construction. The semiotic analysis of monuments explores the strategies used by designers to create and control the interpretations of monuments: how does a tall memorial come to convey imposing meanings of power in a certain context? How does glass come to convey ideals of transparency?

Contemporary semiotic research has demonstrated that the material and the symbolic levels cannot be automatically associated to expression and content respectively (Paolucci 2010). This approach has defined a more complex relation between expression and content and consequently between material and symbolic: both expression/content and material/symbolic are in a mutual relation that defines, from context to context, something as expression/material and something else as content/symbolic. ${ }^{10}$ Following these proposals, the semiotic approach equally grants meaning potential to both the material and the symbolic levels of monuments.

\subsection{The political dimension}

Monuments and memorials are built forms deliberately erected to promote selective and dominant historical narratives.

Memorials and monuments are political constructions, recalling and representing histories selectively, drawing popular attention to specific events and people and obliterating or obscuring others. (Hay et al. 2004: 204)

Monuments contribute to fix in space dominant "discourses on the past" (Violi 2014: 11, our trans.). The discourses on the past are "ideological", i.e. they have a "partial world vision" that selects specific interpretations of the "reality" while concealing others (Eco 1976: 289-290). Monuments embody discourses that inevitably express selective points of view on the past, focusing on convenient events while marginalizing what is discomforting for an elite.

For this reasons, monuments are essential for the articulation of the national politics of memory and identity. ${ }^{11}$ Along with other legal, institutional and commemorative means, political elites use monuments to educate citizens toward "what is and what is not to be remembered of the past" (Tamm 2013: 651). Since memory is the basis of any identity building, monuments play an essential role in "shaping a given community's basic values and principles of belonging" (Tamm 2013: 652). Hence, the establishment of selective monumental landscapes can help political elites to promote a single national identity and to reinforce sentiments of national distinctiveness.

While articulating selective historical narratives, political elites erect monuments to inculcate specific conceptions of the present and encourage future possibilities (Massey 1995: 185; Dovey 1999: 12). In doing so, political elites use monuments to set political agendas and to legitimate or reinforce the primacy of their political power. Therefore, monuments can be used as tools to establish the social dynamics of inclusion and exclusion (Hershkovitz 1997; Hay et al. 2004).

Monuments are the most conspicuous concrete manifestations of political power and of 
the command of resources and people by political and social elites. As such, they possess a powerful and usually self-conscious symbolic vocabulary or iconography that is understood by those who share a common culture and history. (Hershkovitz 1997: 397)

While political elites erect monuments seeking to convey dominant worldviews, the meanings of monuments are always "mutable and fluid" (Hay et al. 2004: 204). Once erected, monuments become "social property" (Hershkovits 1997: 397) and they "can be used, reworked and reinterpret in ways that are different from, or indeed contradictory to, the intentions of those who had them installed" (Hay et al. 2004: 204). The interpretations of monument can also dramatically change over time with the change of social relations, concepts of nation and opinions on past events.

[...] the original meaning is not really written in stone at all. Instead, it might be remembered completely differently later on or become the unexpected site of controversy. The memorial may even become invisible and unnoticed. (Kattago 2015: 185)

In transitional societies, the dominant meanings represented in monuments can suddenly become peripheral and variously resisted at a social level. ${ }^{12}$ The tearing down of monuments erected by Communist authorities was the sign of regime change throughout post-socialist space. In less spectacular ways, monuments of a bygone era can turn into more neutral landmarks. For example, after the fall of Communism, the monument to the Soviet Army in Sofia, capital of Bulgaria, has turned from a sacred memorial into a space of entertainment and leisure. Nowadays, the area of the monument is a popular meeting place for youngsters and attracts skaters and bikers that use it for their tricks.

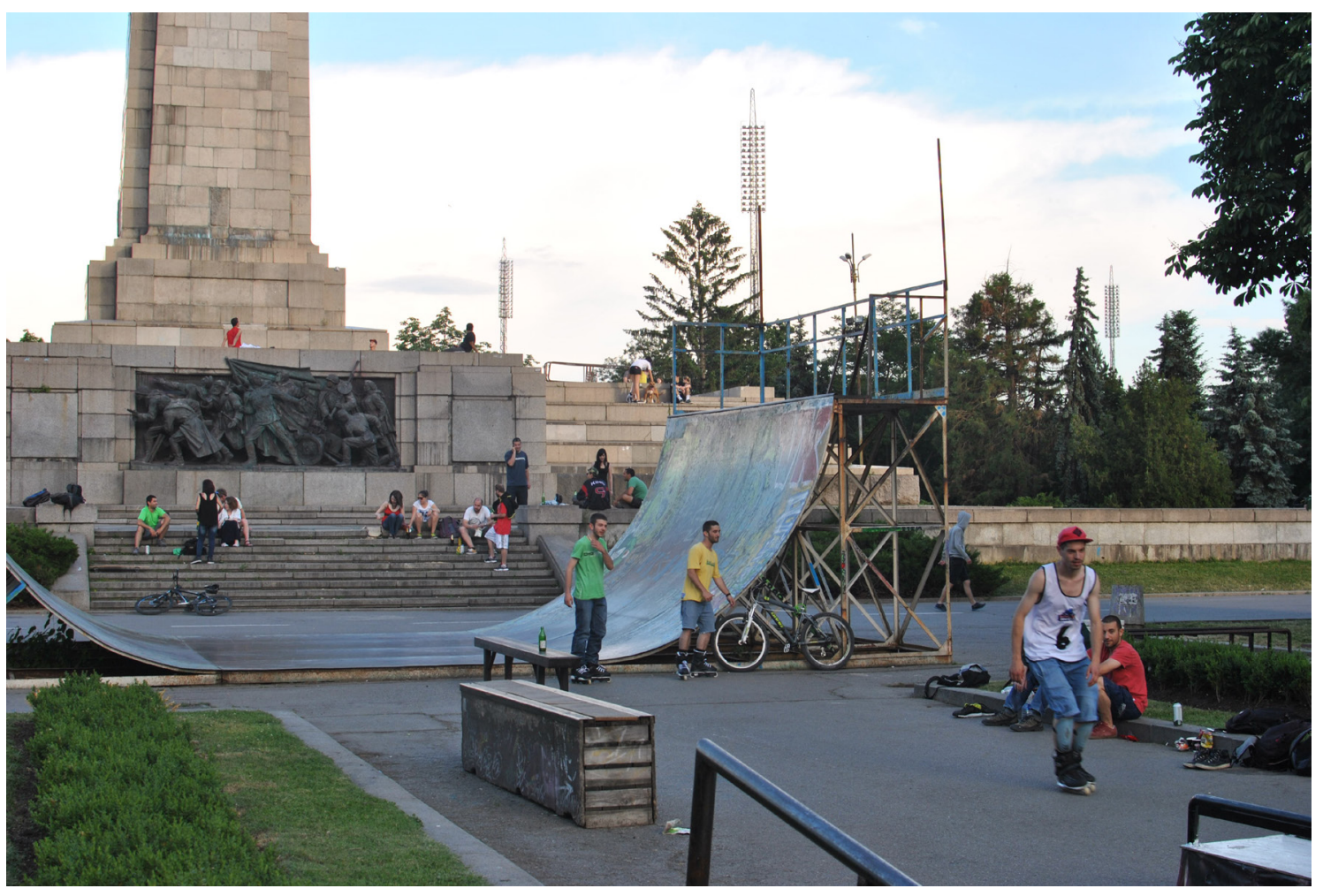

Figure 3.

In some cases, monuments legitimizing the authority of political elites can turn into sites of oppositional and resistant political practices. Hershkovitz (1993) shows how Tiananmen Square in Beijing, the center of political power in China, has embodied traditions of protest and dissidence; Whelan 
(2002) describes how monuments dedicated to British monarchs in Dublin became sites of contestation toward the political regime. Through an examination of the controversies over the World War II Memorial in Washington, DC, Benton-Short proves that memorials wittingly or unwittingly generate debates on identity and memory:

Memorials and other forms of heritage are created in a social/political context where culture, location, class, power, religion, gender and even sexual orientation will influence what is considered to be worthy of preserving as heritage [...]. Because heritage, national identity, and memory are socially constructed, they are also inherently contested [...]. (Benton-Short 2006: 300)

In other cases, monuments considered sacred by their owners may become the object of scorn and ridicule. Atkinson \& Cosgrove (1998) show how the Vittoriano, a huge monument commemorating the first king of united Italy in Rome, has been derided throughout its history.

These cases show that the meanings of monuments are never fixed once and for all and that that designers cannot fully control monument interpretations. Moreover, they show that unexpected and alternative uses continuously reinterpret the original meanings of monuments in ways the designers would never have thought of.

Therefore, monuments and memorials are "dynamic sites of meaning" (Osborne 1998: 453) disposed to elicit multiple interpretations and various emotional responses. The semiotic approach can be useful to analyze the multiple interpretations of monuments drawing attention to both the officially sanctioned meanings of monuments and the various ways they are interpreted or resisted at the social level.

\section{The contextual and inter-textual relations of monuments}

Monuments cannot be analyzed apart from their cultural context. Cultural context largely affects monument interpretations. Culture is the socially constructed signifying system that a group of people actively produces and maintains. ${ }^{13}$ It consists of the basic and shared meanings that guide behavior and channel interpretations of individuals and social communities. Due to its complexity, culture includes different interpretative communities (Yanow 2000). Each interpretative community has a particular way to frame social reality based on specific cultural traits such as language, race, ethnicity, class, religion, political views, socio-economic interests and needs (Yanow 2000; Hajer and Wagenaar 2003).

Eco calls these particular ways of interpreting social reality "encyclopedic competences" (Eco 1986: 2-3). In Eco's term, the "encyclopedia" is a stock of shared signs that interpreters use during interpretative processes. The encyclopedia is subdivided in two levels to include both the cultural knowledge as a whole and the routinized ways to use that knowledge: at the global level, the encyclopedia contains all the potential interpretations circulating in the socio-cultural world; at local levels, it contains routinized sets of instructions to interpret specific portions of the socio-cultural space (Eco 1986: 68; Violi 1992: 103; Lorusso 2010: 108-109; Paolucci 2010: 357-358). In practice, different cultures select relevant local portions of knowledge to delimit specific areas of consensus that differentiate them from other cultures (Hajer and Wagenaar 2003: 27). Thus, different interpretative communities interpret monuments differently on the basis of their shared stock of knowledge: the same monument can be for one community a sacred site of commemoration, for another a source of traumatic memories.

As part of the broader cultural context, the spatial settings in which monuments are located 
largely affect their interpretations. Often the location of monuments has "site specific connection to events and people commemorated" (Benton-Short 2007: 300).

In some cases, monuments are erected in locations they themselves contribute to symbolically and ideologically charge. Frequently spatial settings are reconstructed or redesigned to provide appropriate location for future monuments. In other cases, the manipulations of spatial surroundings can affect the meanings of already existing monuments. For example, the manipulation of spatial surrounding has been variously used in post-socialist cities to lessen the visibility and the "ideological weight" of monuments erected during the Communist era (Ehala 2009: 140). ${ }^{14}$ After the transition, monuments representing Communist leaders were marginalized or even removed from public space, while new political elites establish monuments in accordance with the current social and political system. For example, in Odessa, Ukraine, a statue of Lenin was turned into Darth Vader, the villain of the film series "Star Wars". This replacement was made after the Ukrainian government approved laws to ban Communist symbols in April 2015. The Ukrainian government saw in the excision of Soviet material remains an opportunity to exorcize the traumatic experience of Soviet rule and to build a particular conception of the future.

In this latter case, as texts always reinterpret other texts, ${ }^{15}$ new monuments actively affected the meanings of the monumental space established during the Communist era. Once erected, monuments establish complex relations with the existing built environment. In linguistic and semiotic research, "intertextuality" defines the process through which texts establish relations with other texts circulating within the semiotic space (Manning 1987: 42). Post-structural geographic research has used literary intertextuality to describe the complex relations that built forms establish with other built forms and social practices (Duncan 1990: 22-23). Semiotic analysis takes into account both the cultural context in which monuments are erected and interpreted and the intertextual-like relations monuments establish with one another.

\section{Toward a semiotic approach to monuments}

Different disciplines have studied monuments and memorials using various theoretical and methodological approaches. No doubt this research would be a source of inspiration for future research on monuments and memorials. However, such studies wittingly or unwittingly created gaps between the material, the symbolic and the political dimensions of monuments. Moreover, they variously drew more attention either to the intentions of the designer or to the interpretations of the user. These rigid distinctions fall short of describing the complex interpretative processes around monuments and memorials.

We proposed a semiotic approach to overcome these rigid distinctions predominant in the previous research on monuments and memorials. The main advantages of a semiotic approach to monuments and memorials are the following:

(i) Semiotics provides a holistic approach overcoming distinctions such as visual/political, material/symbolic, designer/user, art/power and so on beforehand. These distinctions may be useful analytical tools in particular cases, but they cannot be projected onto the ontological state of monuments (Lindström et al. 2014: 125). These distinctions should be considered as "participative" rather than oppositional (Paolucci, 2010), defining a mutual process in which terms are directed and received to and by each other. Participative distinctions provide a methodological basis to investigate the meanings of monuments as actively resulting from (1) the interplay of the material, the symbolic and the political dimensions and (2) the interplay between designers' and users' interpretations.

(ii) Semiotics analyzes the meanings of monuments as the results of a "multi-party communication" (Lindström et al. 2014: 126) between different interpretative communities (Yanow 2000). The meanings one attaches to monuments depend on the interrelation between cognitive, axiological 
and emotional functions. Moreover, the everyday practices of users are able to attach new meanings to monuments.

(iii) Semiotic analysis takes into account both the cultural context in which monuments are erected and interpreted and the intertextual relations monuments establish with one another. Specifically, it explores how the meanings of monuments originate from the dialogue between different interpretative communities within a cultural context.

\section{LIST OF FIGURES}

Figure 1. The Bronze Soldier in its current location - the Defence Forces Cemetery of Tallinn, Estonia. Picture taken by the authors in September 2015.

Figure 2. The War of Independence Victory Column in Freedom Square, Tallinn, Estonia. Picture taken by the authors in October 2015.

Figure 3. Skating and biking practices near the monument to the Soviet Army, Sofia, Bulgaria. Picture taken by the authors in June 2015.

\section{NOTES}

1. See for example "Monument" in the Longman Dictionary of Contemporary English, 2009: 1130.

2. For example in Tallinn, capital of Estonia, the relocation in 2007 of a Red Army memorial caused two nights of disorders during which one person perished. This relocation had political consequences damaging the relations between Estonia and the Russian Federation. Moreover, it affects the everyday interactions between Estonian and Russian ethic communities living in Estonia. For further research on this case, see Smith 2008; Pääbo 2008; Torsti 2008; Lehti et al. 2008; Wertsch 2009; Ehala 2009; Mälksoo 2009; Vihalemm and Kalmus 2009; Raun 2009; Kattago 2012; Tamm 2013.

3. Eco (1990b: 145) dubbed this intermediate way "intention of the text" or "intention operis, as opposed to - or interacting with - the intention auctoris and the intention lectoris".

4. From the mid-1980s, the textual paradigm ignited a representational approach toward landscape within human geography. In this context, human geographers largely used the metaphor of landscape as text. Lagopoulos and Lagopoulou (2014: 456-457) registered two main approaches within the geographical research associating text to landscape: landscape-in-text assumes that researchers can reach appropriate understandings of landscape through the investigation of its textual representations. On the other hand, landscape-as-text analyzes actually existing landscapes focusing on the processes of landscape production and interpretation.

5. By "local knowledge" we mean the "web of beliefs" that characterize the interpretation processes of individual and social communities. Local knowledge is specific, concrete, practical and situated in context (Bevir and Rhodes 2010: 75).

6. This category derives from the distinction between hot and cold societies by Levi-Strauss (1990): hot societies are disposed to social change and differentiation and focus on history; cold societies focus on myth and are more static and less differentiated.

7. Greimas and Fontanille (1991) provide a semiotic model to explore the emotional dimensions at the narrative and discursive level. They term "passions" the emotional states of the subjects during specific narrative programs. These emotional states depend on the junctive relation between the subject and the object, i.e. if subjects are joined up with or separated from the objects they value. Each passion differently affects the subject's doing during narrative programs. 
8. Officially called the "War of Independence Victory Column", the Estonian government erected this memorial in 2009 to commemorate the soldiers who fought during the Estonian War of Independence (1918-1920). According to Estonian historical narratives, this war is linked with ideals of freedom and sovereignty, since it culminated with the independence of the Republic of Estonia for the first time in history.

9. Elaborating the Saussurean notion of the sign as a twofold entity, Hjelmslev (1961: 30) defines expression and content "as designations of the functives that contract [...] the sign function". He considers sign as "an entity generated by the connection between an expression and a content".

10. As Paolucci explained (2010), Hjelmslev already conceptualized the mutual relation between expression and content in his Prolegomena to a Theory of Language: "The terms expression plane and content plane [...] are chosen in conformity with established notions and are quite arbitrary. Their functional definition provides no justification for calling one, and not the other, of these entities expression, or one, and not the other, content. They are defined only by their mutual solidarity, and neither of them can be identified otherwise. They are defined only oppositively and relatively, as mutually opposed functives of one and the same function" (Hjelmslev 1961/1943: 60).

11. Following Tamm (2013: 652), we use the terms "national politics of identity/memory" to distinguish the attempt by political elites to create a single collective memory from the other social communities variously calling for the recognition of their memories and identities.

12. Lotman (2005: 205; 1990: 123-204) used the spatial metaphors center and periphery to describe different levels of organization of cultures. At the center of the semiotic space, there were the "most developed and structurally organized languages, and in first place the natural language of that culture" (Lotman 1990: 127). Being more organized, cultures at the center attempted to prescribe conventional norms to the whole culture to generate behavioral norms and codified standards. Usually, the majority of social agents simply embodied these norms and perceived them as their own "reality". However, divergent cultures placed at the periphery of the semiotic space could deviate from the central norms. Lotman considered center and periphery as a dynamic opposition: while organizing laws of self-regulation, central cultures became rigid and thus incapable to develop further (Lotman 1990: 134); on the other hand, being more flexible, peripheral cultures continuously influenced the more organized central cultures.

13. We consider culture as an essentially semiotic concept (Geertz 1973: 24; Othengrafen and Reimer 2012: 52). In order to conceptualize culture in a more critical way, most of the representatives of the so-called "cultural turn" in human geography and sociology investigated culture using semiotic concepts. For example, Raymond Williams (1982: 13) explained that culture is "the signifying system through which necessarily (through among other means) a social order is communicated, reproduced, experienced and explored". Cosgrove and Jackson (1987: 99) considered culture "as the medium through which people transform the mundane phenomenon of the material world into a world of significant symbols to which they gave meanings". Peter Jackson (1989: 2) suggested seeing culture as made from "maps of meaning through which the world is made intelligible".

14. For example, the Estonian government sought to reduce the visibility of the Red Army memorial in the city center of Tallinn to lessen its visibility and "ideological weight" (Ehala 2009: 140). Most of the presented plans suggested balancing the symbolic meanings of the Red Army memorial with Estonian national symbols. However, only minor manipulations were realized: diagonal footpaths replaced the direct access to the memorial, new trees were planted, the eternal flame was removed and the text on the commemorative plaque was modified (Ehala 2009: 140; Smith 2008).

15. Eco (1986: 68) called "unlimited semiosis" this recursive process through which a sign is always reinterpreted by other signs. This is the case also for texts as manifested sets of signs. 


\section{REFERENCES}

Abousnnouga, Gill and David Machin 2013.The Language of War Monuments. London: Bloomsbury Academic.

Anderson, Benedict 1983. Imagined Communities. Reflections on the Origins of Nationalism. London: Verso.

Atkinson, David and Denis Cosgrove 1998. Urban rhetoric and embodied identities: city, nation and empire at the Vittorio Emanuele II monument in Rome 1870-1945. Annals of the Association of American Geographers 88 (1): 28-49.

Benton-Short, Lisa 2006. Politics, public space and memorials: the brawl on the Mall. Urban Geography 27 (4): 297-329.

Bevir, Mark and Roderik A. W. Rhodes 2010. The State as Cultural Practice. Oxford: Oxford University Press.

Caves, Roger W. 2005. Encyclopedia of the city. Oxon: Routledge.

Chandler, Daniel 1995. The Act of Writing: A Media Theory Approach. Aberystwyth: University of Wales.

Cobley, Paul 2001. Narrative. London and New York: Routledge.

Cosgrove, Denis 1989. Geography is everywhere: culture and symbolism in human landscapes. In: Derek Gregory and Rex Walford (eds) Horizons in Human Geography. Totowa: Barnes and Noble Books, 118-135.

Cosgrove, Denis and Peter Jackson 1987. New directions in cultural geography. Area 19: 95-101.

Dovey, Kim 1999. Framing Places: Mediating Power in Built Form. London: Routledge.

Duncan, James S. 1990. The City as Text: The Politics of Landscape Interpretation in the Kandyan Kingdom. Cambridge: Cambridge University Press.

Dwyer, Owen J. 2002. Location, politics, and the production of civil rights memorial landscapes. Urban Geography 23 (1): 31-56.

Eco, Umberto 1972. Towards a semiotic inquiry into the television message. Trans. Paola Splendore. Working Papers in Cultural Studies 6: 103-21.

Eco, Umberto 1976. A theory of semiotics. Bloomington: Indiana University Press.

Eco, Umberto 1979. The Role of the Reader. Bloomington: Indiana University Press.

Eco, Umberto 1986. Semiotics and the Philosophy of Language. Bloomington: Indiana University Press.

Eco, Umberto 1990a. The limits of interpretation. Bloomington: Indiana University Press.

Eco, Umberto (1990b) Interpretation and Overinterpretation: World, History, Texts. The Tanner Lectures on Human Values, Cambridge University. Available from: http://tannerlectures.utah.edu/ documents/a-to-z/e/Eco 91.pdf. [accessed May 12, 2016].

Eco, Umberto 1992. Interpretation and Overinterpretation. Cambridge: Cambridge University Press.

Eco, Umberto 1994. Six Walks in the Fictional Woods. Cambridge: Harvard University Press.

Eco, Umberto1997. Function and sign: the semiotics of architecture. In: Neil Leach (ed) Rethinking Architecture: A Reader in Cultural Theory. New York: Routledge, 182-202.

Eco, Umberto and Paolo Fabbri 1981. Environmental information: a methodological proposal. Human Settlements and Socio-cultural Environment 23: 1-44.

Ehala, Martin 2009. The Bronze Soldier: Identity threat and maintenance in Estonia. Journal of Baltic Studies 1: 139-158.

Geertz, Clifford 1973. The Interpretation of Cultures: Selected Essays. New York: Basic Books.

Greimas, Algirdas J. 1984. Sémiotique figurative et sémiotique plastique. Actes sémiotiques-Documents 60: 1-24. 
Greims, Algirdas J. and Joseph Courtés 1982. Semiotics and Language: An Analytical Dictionary. Bloomington: Indiana University Press.

Greimas, Algirdas J. and Jacques Fontanille 1993[1991]. The Semiotics of Passions. From States of Affairs to States of Feelings. Trans. Paul Perron and Frank Collins, London \& Mineapolis: Minnesota University Press.

Hajer, Maarten A. and Hendrik Wagenaar (eds) 2003. Deliberative Policy Analysis: Understanding Governance in the Network Society. Cambridge: Cambridge University Press.

Harvey, David 1979. Monument and myth. Annals of the Association of American Geographers 69 (3): 362-381.

Hay, lain, Andrew Hughes and Tutton, Mark 2004. Monuments, Memory and Marginalisation in Adelaide's Prince Henry Gardens. Geografiska Annaler 86 (B/3): 201-216.

Hershkovitz, Linda 1993. Tiananmen Square and the Politics of Place. Political Geography 12: 395-420.

Hjelmslev, Louis 1961 [1943]. Prolegomena to a Theory of Language. Madison: The University of Wisconsin Press.

Hobsbawm, Eric and Terrence Ranger (eds) 1983. The Invention of Tradition. Cambridge: Cambridge University Press.

Jackson, Peter 1989. Maps of Meaning: An Introduction to Cultural Geography. London: Unwin Hyman.

Johnson, Nuala 1995. Cast in stone: monuments, geography and nationalism. Environment and Planning D: Society and Space 13: 51-65.

Kattago, Siobhan 2012. Memory and Representation in Contemporary Europe. The Persistence of the Past. Farnham: Ashgate Publishing.

Kattago, Siobhan (ed) 2015. Ashgate Research Companion to Memory Studies. Farnham: Ashgate Publishing.

Koselleck, Reinhart 2002. War memorials as identity formation of survivors. In: Reinhart Koselleck and Todd Samuel Presner (eds) The practice of conceptual history: timing history, spacing concepts. Stanford: Stanford University Press, 285-326.

Lagopoulos, Alexandros Ph. and Karin Boklund-Lagopoulou 2014. Semiotics, culture and space. Sign System Studies 42 (4): 435-485.

Lindström, Kati, Kalevi Kull and HannesPalang2014. Landscape semiotics: Contribution to culture theory. In: Valter Lang and Kalevi Kull (eds) Estonian Approaches to Culture Theory. Tartu: University of Tartu Press, 110-132.

Lefebvre, Henri 1991 [1974]. The Production of Space. Trans. Donald Nicholson-Smith, Oxford: Blackwell Publishers.

Lehti, Marko, Matti Jutila and Markku Jokisipilä 2008. Never-Ending Second World War: Public Performances of National Dignity and the Drama of the Bronze Soldier. Journal of Baltic Studies 39 (4): 393-418.

Lévi-Strauss, Claude 1962. Le Pensée Sauvage. Paris: Plon.

Lorusso, Anna Maria 2010. Semiotica della cultura. Bari: Laterza.

Lotman, Juri M. 1990. Universe of the Mind: A Semiotic Theory of Culture. London \& New York: I.B. Tauris. Lotman, Juri M. 2005[1984]. On the semiosphere. Sign Systems Studies, 33 (1): 205-229.

Lotman, Juri M. and Boris A. Uspenskij 1973. Tipologia della Cultura. Milano: Bompiani.

Mälksoo, Maria 2009. Liminality and Contested Europeanness: Conflicting Memory Politics in the Baltic Space. In: Berg Eiki and Ehin Piret (eds) Identity and Foreign Policy: Baltic-Russian Relations and European Integration. Farnham: Ashgate, 65-83.

Manning, Peter K. 1987. Semiotic and fieldwork. London: SAGE Publication Ltd. 
Marrone, Gianfranco 2009. Dieci tesi per uno studio semiotico della città. Appunti, osservazioni, proposte. Versus 109-111: 11-46.

Marrone, Gianfranco 2010. L'invenzione del testo. Bari: Laterza.

Marrone, Gianfranco 2013. Figure di città. Spazi urbani e discorsi sociali. Milano: Mimesis.

Massey, Doreen 1995. Places and their pasts. Historical Workshop Journal 39 (1): 182-192.

Nanni, Antonio and Federico Bellentani 2016. The meaning-making of the built environment in the Fascist city: a semiotic approach. Manuscript in preparation.

Nora, Pierre 1996. Realms of Memory: Rethinking the French Past. New York: Columbia University Press.

Osborne, Brian S. 1998. Constructing landscapes of power: the George Etienne Cartier monument, Montreal. Journal of Historical Geography 24 (4): 431-458.

Othengrafen, Frank and Mario Reimer 2012.Uncovering the unconscious dimensions of planning. Using culture as a tool to analyse spatial planning practices. Farnham: Ashgate Publishing.

Pääbo, Heiko 2008. War of Memories: Explaining "Memorials War" in Estonia. Baltic Security and Defence Review 10: 5-28.

Panofsky, Erwin 1955. Meaning in the Visual Arts: Papers in and on Art History, Garden City and New York: Doubleday.

Paolucci, Claudio 2010. Strutturalismo e Interpretazione. Ambizioni per una Semiotica "Minore". Milano: Bompiani.

Riegl, Alois 1903. Der modern Denkmalkultus, seine Wesen und seine Entstehung. Wien \& Leipzig: W. Braumüller.

Raun, Toivo U. 2009. Estonia after 1991: Identity and integration. East European Politics and Societies 23 (4): 526-534.

Smith, David J. 2008. "Woe from Stones": Commemoration, Identity Politics and Estonia's "War of Monuments". Journal of Baltic Studies 39 (4): 419-430.

Tamm, Marek 2013. In search of lost time: Memory politics in Estonia 1991-2011. Nationalities Papers, The Journal of Nationalism and Ethnicity 41 (4): 651-674.

Till, Karen E. 2003. Places of Memory. In: John Agnew, Katharyne Mitchell and Gearoid O. Tuathail (eds) A Companion for Political Geography. Oxford: Blackwell, 289-301.

Thürlemann, Felix 1982. Blumen Mythos. In: Paul Klee Analyse Sémiotique de Trios Peintures. Lausanne: L'Age de l'homme.

Torsti, Pilvi 2008. Why do History Politics Matter? The Case of the Estonian Bronze Soldier. In: Juhana Aunesluoma and Pauli Kettunen (eds) The Cold War and the Politics of History. Helsinki: Edita Publishing, 19-35.

Vihalemm, Triin and Veronika Kalmus 2009. Cultural Differentiation of the Russian Minority. Journal of Baltic Studies 40 (1): 95-119.

Violi, Patrizia 1992. Le molte enciclopedie. In: Patrizia Magli, Giovanni Manetti and Patrizia Violi (eds) Semiotica: Storia Teoria Interpretazione. Saggi intorno a Umberto Eco. Milano: Bompiani, 99-113.

Violi, Patrizia 2014. Paesaggi della Memoria. Il trauma, lo spazio, la storia. Milano: Bompiani.

Wertsch, James V. 2008a. Collective memory and narrative templates. Social Research: An International Quarterly of the Social Sciences 75 (1): 133-156.

Whelan, Yvonne 2002. The construction and destruction of a colonial landscape: monuments to British monarchs in Dublin before and after independence. Journal of Historical Geography 28 (4): 508-533.

Williams, Raymond 1982. The sociology of culture. New York: Schocken. 
Withers, Charles W. J. 1996. Place, Memory, Monument: Memorializing the Past in Contemporary Highland Scotland. Ecumene 3 (3): 325-344.

Yanow, Dvora 2000. Conducting interpretative policy analysis. Thousand Oaks \& California: Sage Publications.

Yiftachel, Oren 1998. Planning and social control: exploring the "dark side". Journal of Planning Literature 12 (2): 395-406.

Federico Bellentani is a PhD student at the School of Planning and Geography, Cardiff University, UK.

Mario Panico is a PhD student in Philosophy, Science, Cognition and Semiotics (PSCS), University of Bologna, Italy. 